\title{
Доопераційна серцева недостатність при інфекційному ендокардиті
}

\author{
Колтунова Г. Б., Сенько О. Г., Хорощак В. Я., Крикунов О. А., Малишева Т. А., \\ Списаренко С. П.
}

\author{
ДУ «Національний інститут серцево-судинної хірургії імені М. М. Амосова НАМН» (Київ)
}

\begin{abstract}
Серцева недостатність $€$ найбільш частим і найбільш важким ускладненням інфекційного ендокардиту (IE) з частотою реєстрації від $42 \%$ до $60 \%$ випадків IE нативних клапанів серця. Мета роботи - виявити діагностичні показники та терміни оперативного втручання при IE, ускладненому серцевою недостатністю $(\mathrm{CH})$. Висновки. Діагностувати доопераційну СН можна за клінічними та лабораторними показниками, за ехокардіографічними даними, за функціональним класом NYHA. Наявність СН є принциповим показанням до проведення ургентного хірургічного втручання у більшості пацієнтів з IЕ. Доопераційна СН $€$ найважливішим предиктором госпітальної, шестимісячної та річної летальності.
\end{abstract}

Ключові слова: інфекційний ендокардит, серцева недостатність, ургентне хірургічне втручання.

Інфекційний ендокардит асоціюється зі значними рівнями захворюваності та летальності. У низці опублікованих досліджень показники госпітальної летальності коливаються від $15 \%$ до $20 \%$, а однорічна летальність дорівнює 40\% [1]. У США шорічно реєструється близько 15000 випадків інфекційного ендокардиту [1]. Різноманітні доопераційні органні ускладнення роблять свій внесок у високі показники летальності, особливо серцева недостатність, що реєструється у $40 \%$ хворих на IE [2]. Серія досліджень виявила зниження рівня летальності при проведенні кардіохірургічного втручання у хворих на IE, ускладнений серцевою недостатністю, що знайшло відображення в міжнародних рекомендаціях стосовно показань і термінів хірургічної корекції при IE [2, 3].

Рівні госпітальної летальності при ІЕ лівих відділів серця, ускладненому серцевою недостатністю, склали від $24 \%$ до $43 \%$ випадків і були пов'язані 3 неконтрольованою інфекцією, неврологічними ускладненнями, ендокардитом, спричиненим $S a u$ reus [5-7]. Розвиток серцевої недостатності на пізніх етапах IE також асоціюється з високою летальністю [8]. Ступінь серцевої недостатності представлений як найсильніший предиктор не тільки госпітальної, а й однорічної летальності [10]. В одному з останніх одноцентрових досліджень клапанне хірургічне втручання було виконане у 46\% хворих на IЕ лівих відділів серця, ускладнений серцевою недостатністю без урахування ступеня важкості, що привело до зниження госпітальної та однорічної летальності [4]. Раніше опубліковане дослідження виявило зменшення рівнів 6-місячної виживаності хворих після хірургічного втручання з приводу IE залежно від ступеня важкості доопераційної серцевої недостатності (NYHA клас III або IV) [15].
Серцева недостатність при IE - це результат складної взаємодії між динамічною адаптацією серцевосудинної системи до інфекційного процесу, імунної відповіді організму та наслідків запропонованої терапії. Патофізіологія цього процесу мультифакторна; описано системні, клітинні та позаклітинні механізми, включаючи перерозподіл коронарного кровотоку, міокардіальне ушкодження, комплімент-асоційоване зниження скоротливої здатності міоциту, цитокін-індуковану активацію нейтрофілів, порушення регуляції кальцієвих каналів та мітохондріальну дисфункцію $[11,12]$. При IE міокард функціонально та структурно ушкоджується прозапальними цитокінами 3 порушенням функції мітохондрій. Хімічні речовини, включаючи ендотоксини бактерій та оксид азоту, $є$ основними медіаторами ушкодження серцевого м'яза при IE.

До розвитку серцевої недостатності призводить не тільки дифункція міокарда, а й ушкодження клапанних структур. Виникнення клапанної регургітації або наростання вже існуючої недостатності аортального чи мітрального клапана, а також формування внутрішньосерцевої фістули призводить до розвитку серцевої недостатності при IE [13]. Недостатність мітрального клапана при IE може виникати внаслідок обриву хорд, розриву стулки, перфорації стулки або порушення замикальної функції стулок через розростання масивних вегетацій. У деяких випадках інфікування передньої стулки мітрального клапана відбувається вторинно внаслідок струменя регургітації з ураженого інфекцією аортального клапана. Наступне формування аневризматичного ушкодження передньої стулки мітрального клапана може призвести до ії перфорації [15].

Діагностувати СН можна за клінічними ознаками, за ехокардіографічними (ЕхоКГ) даними, за функціо- 
нальним класом NYHA, нестабільністю гемодинаміки, а також за Framigham та АНА-рекомендаціями.

До клінічних проявів СН можна віднести задишку, інтерстиціальний набряк легень та кардіогенний шок [16]. За результатами ICE Prospective Cohort Study, хворі на IE, ускладнений $\mathrm{CH}$, у 66\% випадків належали до III або IV функціонального класу за NYHA.

Важливим методом дослідження залишається проведення трансторакального ЕхоКГ. Перфорації стулок, вторинні ушкодження та аневризматичні зміни стулок краще оцінюються за допомогою черезстравохідного ЕхоКГ $[8,9]$. Ехокардіографія також важлива для оцінки гемодинамічних наслідків клапанної регургітації, вимірювання тиску в легеневій артерії, виявлення випоту в перикардіальній порожнині та спостереження за систолічною функцією лівого шлуночка [6]. Значна кількість досліджень присвячена лівошлуночковій систолічній дисфункції при IE, при цьому інші варіанти міокардіальної дисфункції описані менше [10]. До таких варіантів можна віднести лівошлуночкову діастолічну дисфункцію, правошлуночкову дисфункцію, які можуть бути виявлені як окремо, так і в поєднанні [8].

Серед лабораторних показників $\mathrm{CH}$ вирізняють креатинінфосфокіназу та креатинінфосфокіназу-МВ. Підвищення цих показників свідчить про ушкодження міокарда (інфаркт, міокардит). Важливим біохімічним маркером для діагностики СН при IЕ залишається про-B-подібний натрійуретичний пептид (proBNP) [5]. В-подібний натрійуретичний пептид - це гормон, який виділяється кардіоміоцитами в шлуночках серця у відповідь на розтягнення, викликане збільшенням об'єму крові у шлуночку. ProBNP - прогормон 3 76-амінокислотним $\mathrm{N}$-кінцевим неактивним білком, який відщеплюється від молекули для вивільнення натрійуретичного пептиду. Підвищені рівні серцевих тропонінів та proBNP асоціюються з несприятливими наслідками [7].

Наявність СН є принциповим показанням до проведення ургентного хірургічного втручання у більшості пацієнтів з IE [16]. Терміни оперативного втручання зумовлюються гемодинамічним статусом пацієнта. Екстрене оперативне втручання проводиться протягом 24 годин з моменту госпіталізації, ургентне оперативне втручання - протягом декількох діб. Хiрургія показана хворим на IE, ускладнений $\mathrm{CH}$, з вираженою аортальною або мітральною недостатністю, внутрішньосерцевими фістулами або обструкцією клапана вегетаціями. Хірургія також показана пацієнтам із гострою вираженою аортальною або мітральною недостатністю без клінічних проявів $\mathrm{CH}$, але 3 ехокардіографічними ознаками підвищеного лівошлуночкового кінцево-діастолічного тиску, підвищеного тиску в лівому передсерді або підвищеного тиску в легеневій артерії [16].

\section{Таблиця 1}

Показання та строки хірургічного втручання при клапанному ендокардиті

\begin{tabular}{llll}
$\begin{array}{l}\text { Показання до хірургічного } \\
\text { втручання }\end{array}$ & $\begin{array}{l}\text { Оператив- } \\
\text { ний статус }\end{array}$ & Клас & Рівень \\
\hline Серцева недостатність & & & \\
\hline $\begin{array}{l}\text { 1. ІЕ аортального або мітрального } \\
\text { клапана з гострою вираженою }\end{array}$ & & & \\
$\begin{array}{l}\text { недостатністю, обструкція або } \\
\text { фістула, що призводить до реф- } \\
\text { рактерного набряку легень або } \\
\text { кардіогенного шоку }\end{array}$ & операція & I & В \\
\hline $\begin{array}{l}\text { 2. ІЕ аортального або мітрального } \\
\text { клапана з вираженою }\end{array}$ & & & \\
недостатністю або обструкція, & Ургентна & & \\
що призводить до появи & операція & & В \\
СН або ЕхоКГ-ознак низької & & & \\
гемодинамічної толерантності & & &
\end{tabular}

Хірургічне втручання проводиться в екстреному порядку, незалежно від активності інфекційного процесу, у хворих на IE, ускладнений інтерстиціальним набряком легень або кардіогенним шоком, рефрактерним до медикаментозного лікування [6]. Наявність масивних вегетацій на клапані також є показанням до ургентної операції і при незначному ступені вираженості СН. Ургентне втручання проводиться при вираженій аортальній або мітральній недостатності 3 масивними вегетаціями на стулках клапана без ознак СН [9] (табл. 1).

Доопераційна $\mathrm{CH} є$ важливим фактором у міжнародних анестезіологічних і кардіохірургічних шкалах ризику хірургічного втручання (EUROSCORE, APACHE, APACHE II), що значно погіршує результати лікування.

Реєстрація СН у хворих на IE на доопераційному етапі свідчить про ушкодження міокарда та судинного русла і неможливість серцево-судинної системи забезпечити потреби організму пацієнта. Доопераційна СН зумовлює використання кардіотонічних засобів до хірургічного втручання, значно ускладнює інтраопераційне ведення, а також потребує високих доз інотропної підтримки в післяопераційному пеpioдi, що веде до виснаження скомпрометованого міокарда та негативно впливає на результати хірургічного втручання. Доопераційна $\mathrm{CH} є$ найважливішим предиктором госпітальної, 6-місячної та річної летальності [17].

Висновки. Група пацієнтів, хворих на інфекційний ендокардит, посідає особливе місце в спектрі пацієнтів кардіохірургічного профілю. Такі хворі потребують як своєчасної діагностики IE, ускладненого СН, так i, головне, своєчасного хірургічного втручання. До особливостей цієї патології відносять не тільки 
швидкість розвитку та обсяг внутрішньосерцевих порушень, а й негативний вплив інфекційного процесу на міокард. Поєднання цих факторів призводить до розвитку доопераційної серцевої недостатності, що негативно позначається на безпосередніх та віддалених результатах хірургічного лікування інфекційного ендокардиту.

\section{Література}

1. Flynn A, Chokkalingam Mani B, Mather PJ. Sepsisinduced cardiomiopathy: a review of pathophysiologic mechanisms. Heart Fail Rev. 2010;15(6):605-611. Review.

2. Hochstadt A, Meroz Y, Landesberg G. Myocardial dysfunction in severe sepsis and septic shock: more questions than answers? J Cardiothorac Vasc Anesth. 2011; 25(3):526-535.

3. De Geer L, Engvall J, Oscarsson A. Strain echocardiography in septic shock - a comparison with systolic and diastolic function parameters, cardiac biomarkers and outcome. Crit Care. 2015; 19:122-122.

4. Klouche K, Pommet S, Amigues L, Bargnoux AS, Dupuy AM, Machado S. Plasma brain natridiuretic peptide and troponin levels in severe sepsis and septic shock: relationships with systolic myocardial dysfunction and intensive care unit mortality . J Intensive Care Med. 2014;29(4):229-237.

5. Landesberg G, Jaffe AS, Gilon D, Levin PD, Goodman $\mathrm{S}$, Abu-Baih A. Troponin elevation in severe sepsis and septic shock: the role of left ventricular diastolic dysfunction and right ventricular dilatation. Crit Care Med. 2014;42(4):790-800.

6. Fichet J, Sztrymf B, Jacobs FM. Echographic evaluation of ICU patients with tissue Doppler imaging: more studies and more consensus are still needed . Crit Care. 2012;16(3):433-433.

7. Brown SM, Pittman JE, Hirshberg EL, Jones JP, Lanspa MJ, Kuttler KG, , et al. Diastolic dysfunction and mortality in early severe sepsis and septic shock: a prospective observational echocardiography study. Crit Ultrasound J. 2012;4(1):8-18.

8. Landesberg G, Gilon D, Meroz Y, Georgieva M, Levin PD, Goodman S. Diastolic dysfunction and mortality in severe sepsis and septic shock. Eur Heart J. 2012;33(7):895-903.

9. Rolando G, Valenzuela Espinoza ED, Avid E, Welsh S, Del Pozo J, Vasquez AR. Prognostic value of ventricular diastolic dysfunction in patients with severe sepsis and septic shock. Rev Bras Ter Intensiva. 2015;27(4):333-339.
10. Dantas VC de S, Costa ELV. A look at the diastolic function in severe sepsis and septic shock. Revista Brasileira de Terapia Intensiva. 2015;27(4):307-308. doi:10.5935/0103507X.20150052.

11. Kahveci G, Bayrak F, Mutlu B, Bitigen A, Karaahmet T, Sonmez K, Izgi A, DegertekinM,BasaranY.Prognostic value of $\mathrm{N}$-terminal pro-B-type natriuretic peptide in patients with active infective endocarditis. Am J Cardiol. 2007. - Vol. 99. - P.1429-1433.

12. Lopez J, Sevilla T, Vilacosta I, Garcia H, Sarria C, Pozo E, Silva J, Revilla A, Varvaro G, delPalacio M, Gomez I, San Roman J A. Clinical significance of congestive heart failure in prosthetic valve endocarditis. A multicenter study with 257 patients. Rev Esp Cardiol (Engl Ed). - 2013. Vol. 66. - P. 384-390.

13. Hubert S, Thuny F, Resseguier N, Giorgi R, Tribouilloy C, Le Dolley Y, Casalta JP, Riberi A, Chevalier F, Rusinaru D, Malaquin D, Remadi JP, Ammar AB, Avierinos JF, Collart F, Raoult D, Habib G. Prediction of symptomatic embolism in infective endocarditis: construction and validation of a risk calculator in a multicenter cohort. J Am Coll Cardiol. - 2013. - Vol. 62. - P. 1384-1392.

14. Olmos C, Vilacosta I, Fernandez C, Lopez J, Sarria C, Ferrera C, Revilla A, Silva J, Vivas D, Gonzalez I, SanRoman J A. Contemporary epidemiology and prognosis of septic shock in infective endocarditis. Eur Heart J. 2013. - Vol. 34. - P. 1999-2006.

15. Mirabel M, Sonneville R, Hajage D, Novy E, Tubach F, Vignon P, Perez P, LavoueS, Kouatchet A, Pajot O, Mekontso-Dessap A, Tonnelier JM, Bollaert PE, Frat JP, Navellou JC, Hyvernat H, Hssain AA, Timsit JF, Megarbane B, Wolff M, Trouillet JL. Long-term outcomes and cardiac surgery in critically ill patients with infective endocarditis. Eur Heart J. - 2014. - Vol. 35. - P. 11951204.

16. 2015 ESC Guidelines for the management of infective endocarditis: The Task Force for the Management of Infective Endocarditis of the European Society of Cardiology (ESC).

17. Belletti, Alessandro et al. Incidence and Predictors of Postoperative Need for High-Dose Inotropic Support in Patients Undergoing Cardiac Surgery for Infective Endocarditis. Journal of Cardiothoracic and Vascular Anesthesia. - 2017. - pii: S1053-0770(17)31000-5.

\title{
Preoperative heart failure in infective endocarditis
}

\author{
Koltunova G. B., Senko O.G., Khoroshyak V. Y., Krikunov O. A., Malysheva T. A., Spysarenko S. P. \\ National M. M. Amosov Institute of Cardiovascular Surgery National Academy of Medical Sciences of Ukraine (Kyiv)
}

Heart failure (HF) is the most frequent and most severe complication of infective endocarditis (IE), which rates from $42 \%$ to $60 \%$ of cases of native IE. Objectives: to review diagnostic criteria and terms of surgical intervention in IE, complicated by HF. Preoperative HF in patients with IE indicates damage of the myocardium and vascular bed with subsequent inability of the cardiovascular system to meet the needs of the patient's body. Myocardial dysfunction in IE is a complex entity due to the dynamic adaptation of the cardiovascular system to the disease process, the host response, and the effects of medical therapy. Not only myocardial depression leads to the development of HF in patients with IE, but valve structures impairment as well. 
HF is mainly caused by new or worsening severe aortic or mitral regurgitation, although intracardiac $₫$ stulae and, more rarely, valve obstruction may also lead to HF. Presentation of preoperative HF includes clinical and laboratory parameters (New York Heart Association class). Echocardiographic data is of crucial importance for initial evaluation and follow-up. HF in patients with IE causes administration of inotropic support before surgical intervention, greatly complicates intraoperative management and bypass weaning, requires high-doses inotropic support upon admission to the postoperative intensive care unit. This leads to depletion of compromised myocardium and adversely affects the results of surgery. Preoperative HF is an important factor in the international anesthetic and cardiac surgical risk scales (EUROSCORE, APACHE, APACHE II), which significantly impairs the results of treatment. A series of studies revealed reduction in hospital mortality after cardiac surgery in patients with IE, complicated by heart failure, that was reflected in international recommendations on indications and terms of surgical correction in IE. Preoperative HF is the most important predictor of hospital, 6-month and 1-year mortality.

Conclusions. Patients with IE share a special part in the spectrum of cardiac surgery community. Such patients need both timely diagnosis of IE, complicated with HF, and, most importantly, timely surgical intervention. HF is principal indication for urgent surgical intervention in patients with IE. The peculiarities of this pathology include not only the quickness of development and the extent of intracardiac impairment, but also the negative influence of the infective process on the myocardium. Combination of these factors leads to development of preoperative HF, which negatively affects the immediate and long-term results of surgical treatment of infective endocarditis.

Key words: infective endocarditis, heart failure, urgent surgical intervention. 